\title{
Coping Strategies and Psychological Well-Being of Guidance and Counselling Teachers in Schools
}

\author{
Nur Jannah Bali Mahomed, Ku Suhaila Ku Johari, Mohd Izwan Mahmud \\ Faculty of Education, National University of Malaysia, Bangi, Selangor Darul Ehsan, Malaysia \\ Email: suhaila@ukm.edu.my
}

How to cite this paper: Mahomed, N. J. B., Johari, K. S. K., \& Mahmud, M. I. (2019). Coping Strategies and Psychological Well-Being of Guidance and Counselling Teachers in Schools. Creative Education, 10, 3028-3040.

https://doi.org/10.4236/ce.2019.1012227

Received: October 18, 2019

Accepted: November 26, 2019

Published: November 29, 2019

Copyright $\odot 2019$ by author(s) and Scientific Research Publishing Inc. This work is licensed under the Creative Commons Attribution International License (CC BY 4.0).

http://creativecommons.org/licenses/by/4.0/

\begin{abstract}
In the era of globalization and with the emergence of the Industrial Revolution 4.0, Malaysia, as a developing country, put much emphasis in education along with other important sectors. This scenario leads to the increasing role of guidance and counselling teachers in the school in producing great and knowledgeable students. This responsibility causes guidance and counselling teachers to face various challenges that may put pressure on the profession. Guidance and counselling teachers need to prepare themselves with coping strategies in order to maintain psychological well-being which is an important aspect for the development of the services offered. The results of past research found that coping strategies contributed to the psychological well-being of guidance and counselling teachers and improved the quality of guidance and counselling services. Therefore, this paper reviews the factors of coping strategies as contributors to psychological well-being besides identifying the needs in strengthening the coping strategies and psychological well-being of guidance and counselling teachers. It is suggested that future studies should focus on quantitative and qualitative studies in order to have a better understanding of these issues.
\end{abstract}

\section{Keywords}

Psychological Well-Being, Coping Strategies, Guidance and Counselling Teacher

\section{Introduction}

Malaysia, as a modernize developing country, places education in a very high priority as it aims to produce students who are balanced physically, emotionally, spiritually and intellectually. As a result, the role of guidance and counselling 
teachers has become increasingly challenging in developing students so that they are not lagging in the fast-paced development of the country. The scope of roles of guidance and counselling teachers focuses on four areas namely student development, improving student discipline, career education as well as mental and psychosocial well-being (Ministry of Education Malaysia's (MOE) Release, Number 12, 2012). These areas should be at the heart of the school's guidance and counselling services in order to meet the expectations of MOEs to produce students who have the potential and are able to keep up with current technological changes.

Guidance and counselling teachers are responsible in helping the various needs of students from different settings. In addition, there is no exception in helping gifted students in academic and non-academic engagement and the teachers need to be aware of the slight differences in cognitive, affective and behavioral angles exhibited by their students beyond the norm (Abu Yazid, 2016). Furthermore, the findings of Noriah Mohd Ishak \& Abu Yazid (2014) show that among the gifted students, $60 \%$ prefer to solve their own personal problems, $30 \%$ talk to their teachers and peers when they have personal problems, only $7 \%$ will consult a counselor for help and the remaining $3 \%$ of students share their problems with their parents. The findings also show that students prefer to get career counseling and academic guidance rather than share their personal problems. This clearly shows that the task of guidance and counselling teachers is not easy as they need to deal with the various challenges of these diverse students.

Meanwhile, the government would produce 11,000 professional counsellors, in order to ensure that there is a sufficient number of counsellors to face the increasingly complex social issues. The demands of adding the number of counsellors surely affected the guidance and counselling teachers who are facing students with various problems and conflicts, especially in the areas of personal development and discipline. This is because students between the ages of 13 and 19 are in a transitional stage where uncertainties and hesitations appear (Azlin et al., 2017). Problems arise when they befriend teenagers who have disruptive behaviours which can lead to them being involved with disciplinary problems in school. In carrying out this responsibility, the profession is exposed to a variety of stressful situations that affect the well-being of guidance and counselling teachers in giving their service at schools. The well-being element is one that the counselling service profession cannot ignore. Mc Leod \& Mc Leod (2014) listed some of the aspects that counsellors need to consider in mastering the therapeutic techniques as well as reinforcing training on current issues, for example, disability issues, cultural differences, adherence to service ethics guidelines, career planning and maintaining well-being in counselling practice. The practice of maintaining well-being, especially psychological well-being, must be taken seriously to ensure that guidance and counselling teachers perform well. Therefore, this review paper intends to explore the coping strategies and psychological well-being of counsellors, in general with a focus on the guidance and counselling teachers. 


\section{Well-Being Issues in Counselling Profession}

Counsellors view themselves as different from other people. They describe themselves as intelligent individuals in the pursuit of life's challenges, but they often forget that they are also ordinary people. Compassion fatigue and any other kinds of fatigues would reduce the ability of the counsellors to bear the suffering of others (Figley, 2002; Copley, 2013). In the context of Malaysia, the study showed that the well-being of guidance and counselling teachers was still at a moderate level (Farisma, 2017; Ng, 2015). While some studies found that guidance and counselling teachers were heavily exposed to stress and burnout issues (Prema 2011; Jafny, 2012; Huat, 2018). There are a number of factors that might lead to guidance and counselling teachers being in stressful role conflict, such as: 1) off-field work, 2) a large list of tasks; 3) administrators and academic teachers' perceptions of the job scope of guidance and counselling teachers, iv) students' expectations of guidance and counselling teacher, as well as factors related to physiological, emotional and health disorders (Prema, 2011). Furthermore, counsellors with less than five years of working experience are less confident in conducting family counselling due to lack of training and education while they were studying at university (Nor Hayati Nor, 2014). This clearly shows that guidance and counselling teachers face difficult situations in their career and personal life, and this must be addressed in order for clients to receive good quality services.

Meanwhile, in the West, counsellors face similar issues such as careers and personal conflicts that result in stress, burnout and compassion fatigue (Smith, 2017). In addition, counsellors are tasked to work with the populations which could impede good self-care and make it difficult for them to maintain their well-being (Cummins et al., 2007). In fact, many previous studies have identified that the counselling service profession is exposed to burnout issues (Coaston, 2017; Mullen \& Crowe, 2017; Kim \& Lambie, 2018). Hence, school counsellors face a variety of challenging demands that lead to stress, empathy fatigue, emotional exhaustion, instability and subsequently cause the counsellors to quit their job (Mullen \& Crowe, 2017). In addition, a study by Mullen and Gutierrez (2016) on 915 school counsellors found that the higher the burnout rate, the lower the level of counselling service provided to the students in school. Similarly, (Mullen et al., 2017 \& Friedman, 2017) explained that school counsellors who are stressed and burnout would affect and reduce their job satisfaction. Furthermore, Bardhoshi et al. (2014) found that unhealthy work environment would affect counsellor's personal life especially when being forced to do tasks outside of their job scope such as clerical tasks, administrative tasks and additional workloads as they would lead to burnout. The experience of burnout causes the counsellors to experience emotional exhaustion, which impaired their competence and make them feel less satisfied with their job. School counsellors might face chronic fatigue or feel useless and might abandon their careers due to rigid school systems and lack of support (Young \& Lambie, 2007; Kim \& Lam- 
bie, 2018). In addition, Simpson et al. (2018) also found that psychologists were faced with competing emotional demands that increased the risk of burnout and the study showed that burnout was a result of organizational and personal factors, including psychologists' personal beliefs and coping strategies. Therefore, counsellors need to be creative and assertive in taking care of themselves as well as improving their well-being in order to provide good quality service.

What makes matters worse is the second-hand depression problem (Hunter, 2016). Counsellors with second-hand depression might have some of the following characteristics. First, this second-hand depression might include burnout and all types of stresses that are only relevant to the counselling professionals, which includes the counselling environment and the nature of the counsellor's work as well as the stress from the counsellors' daily life. Second, it involves the compassion fatigue as a result of the counsellors retaining a painful feeling because of empathy for their client. Third, it involves negative feelings and thoughts that resulted from the clients' stress over a given period of time due to counsellors spending a lot of time with the clients who have cynical, awkward, pessimistic, and negative thoughts. Fourth is the severity of the second-hand depression. The second-hand depression is different from burnout and compassion fatigue as it involves two factors, namely severity and counsellor's recovery period. Counsellors who are severely trapped in depression would no longer be able to manage their own thoughts or feelings, let alone clients' negative thoughts and hurtful feelings, which would affect their self-care. Wilkerson's (2009) study found that school counselors reported higher emotional exhaustion scores compared to other mental health professionals, with higher personal achievement than usual, but the overall sub-scale of regret scores fell below the norm. Therefore, the results of this study indicate that school counselors were personally engaged with their clients, although they were somewhat emotionally exhausted, and yet they had a relatively healthy job satisfaction. All the problems and conflicts faced by the guidance and counselling teachers lead to various issues such as stress, burnout, compassion fatigue, depression, as well as instability. These issues negatively affect the quality of counselling services. Therefore, the well-being of the school counsellor should be emphasized.

\section{Psychological Well-Being of Counsellers}

Factors such as lack of self-care could lead to compassion fatigue. According to Skovholt et al. (2001), the counsellors in training were exposed to the needs of this career and sometimes focused on other things. However, most counselling training focus a lot on how to care of clients, and little attention is given to self-care. Even though counsellors might face the challenge of finding time and energy to engage in self-care, it is still crucial for them to take care of their well-being as it is their personal and professional responsibility as a counsellor. The past researchers provided different views and discussions on the well-being element. Goodman et al. (2017) explained that Bradburn's (1969) "Hedonic 
Balance Model" suggested that well-being could be maximized with a higher ratio of positive effects to the negative effects. In addition, Diener's Tripartite Model of Subjective Well-being enhanced Bradburn's emotional focus by incorporating cognitive components to the extent that one's life was viewed as satisfying or close to the ideal (Goodman et al., 2017). In addition, Ryff s (1989) psychological well-being model categorizes six dimensions that were more closely related to ancient Greek philosophy and psychological theories of humanistic tradition, existence, and development. Besides, Keyes (1998) combined Diener's subjective well-being dimension with Ryff s psychological well-being but felt that it did not include the third type of well-being, which was social well-being, although one dimension of psychological well-being was about one's social relationship level (Goodman et al., 2017). On the other hand, subjective well-being was well known to dominate well-being studies, but Ryff (1989) responded by arguing to explore a more inclusive concept of well-being that included a broader range of what was meant by "good". As the two well-being studies had evolved, they were often compared and contrasted (Heintzelman, 2018). However, the psychological well-being of Ryff (1989) had been widely used and proven and the results were undeniable as it was an element that was able to maintain personal care especially for counsellors.

Ryff $(1989,1995)$ described psychological well-being of individuals as someone who did not only felt happy and free from negative emotions but also driven by positive attitudes toward themselves and their past, able to adapt positively to an environment, had autonomy, had positive relationships with others, had clear goals of life and had continuous self-development. According to Ryff and Keyes (1995) based on Ryff's (1989) model of psychological well-being, the first six dimensions of psychological well-being are defined as; self-acceptance where high scores for this dimension indicate that individuals have a positive attitude toward themselves; recognize and accept many aspects of themselves, including good and bad qualities; feel positive about the past, while the low scores indicate that individuals feel dissatisfied with themselves, frustrated with what had happened in their life, conflicted about a particular personality, wanted to be different from themselves. The second dimension is the positive relationships with others; a high score for this dimension indicates that individuals have friendly, satisfactory, trusting relationships with others; are concerned about the welfare of others; are able to have a high degree of empathy, love, and intimacy; are understanding as well as having the attitude of tolerance in human relationships. Furthermore, low scores for this dimension indicate that individuals have less affinity and trust with others; find it difficult to be friendly, open, and caring about others; are isolated and frustrated in interpersonal relationships; are unwilling to make compromises to maintain important relationships with others. The third dimension is autonomy in which the high score indicate that individuals are self-reliant and independent, able to withstand social pressure for thinking and acting, regulate behaviour from within, and evaluate themselves by personal standards. Whereas low scores for this dimension indicate that indi- 
viduals are concerned about others' expectations and judgments, depend on the judgment of others to make important decisions, respond to social pressure for thinking and acting.

Meanwhile, for the dimension of environmental mastery, a high score indicates that individuals have a strong sense of mastery in managing the environment, controlling a variety of external activities, effectively utilizing environmental opportunities, and are able to choose or create suitable contexts that fit their needs and personal values. The low score in this dimension indicates that individuals have difficulty managing daily affairs, feel unable to change or improve the surrounding environment, are unaware of the opportunities around them, or have little control over the outside world. In addition, the dimension of life goal, a high score indicates that the individuals have a goal in life, a sense of life, a sense of present and past life, hold a belief that life is meaningful, and have purposes in life. Low scores indicate that individuals have less meaning in life; have less purpose, less sense; not seeing the purpose of the past life; and have no view or belief that gives meaning to life. The final dimension is personal growth, the high score indicates that the individuals have a continuous sense of development, see themselves in a positive growth and development, are open to new experiences, realize their own potential, see their own improvements as a person and in their behaviour over time, change by seeking more knowledge and be more effective. The low score in this dimensional indicates that individuals have low self-esteem, lack of improvement or development over time, feel bored and disinterested in life, feel unable to develop new attitudes or behaviours.

In addition, there are several studies that supported the importance of psychological well-being in the counselling services profession which could prevent burnout, stress, personal instability and compassion fatigue among counsellors (Bilot, 2012; Puig et al., 2012; Beaumont et al., 2016; Can, 2018). Another dimension that begins to catch the attention of Western researchers is the coping strategy that is strongly linked to the career as a counsellor and could help with the challenges of burnout, stress and emotional exhaustion.

\section{The Coping Strategies in the Counselling Profession}

According to the transactional theory, coping involves a cognitive and behavioural effort to constantly change in order to manage demands whether external or internal, which is a source of power of a person. In addition, it involves conscious and deliberate actions that were used when someone evaluated the situation as stressful (Lazarus \& Folkman, 1984). Coping strategies are the mechanisms or processes that play a role in managing stress by balancing the challenges using existing self-directed approaches such as emotional ability, social relationships and personality traits. In addition, this theory describes coping strategies as means to either directly manage stress (problem-focused behaviour, PFC) or control emotions arising from stress (emotion-focused behaviour, EFC). The PFC is generally associated with efforts to improve psychological well-being, 
personal care, and health-related quality of life, while EFC is associated with lower levels of psychological well-being and health-related quality of life (Biggs, Brough, \& Drummod, 2017). Furthermore, Krok (2008) defines coping strategies as an approach to assess and respond to stressful situations. Meanwhile, the use of coping depends on the degree of the stress. If it is high, more coping strategies would be used by individuals and the coping strategies would act to compensate for the negative effects of stress affecting the well-being of the individuals ( $\mathrm{Lu}, 1989)$. From another point of view, coping is also defined as a person using cognitive and behavioural strategies to manage external demands or stressful situations (De Ridder, 1997). In addition, coping is an effort to overcome stress in order to produce better mental health rather than attempting to avoid the stress (Clarke, 2006).

From a broader scope, Carver et al. (1989) described five types of problems-focused coping; first, active coping involves the process of taking steps to eliminate or reduce stress and its effects. It includes starting an action, increasing one's efforts, and trying to use coping step by step. Second, planning refers to thinking how to deal with stress. It involves thinking of various ways that could be used to solve the problem. Third, suppression of competing activities means putting other projects in the background and trying to avoid being distracted by other events to deal with stress. Fourth is coping action that involves the process of waiting for the right opportunity to solve the problem and avoid taking early action. A person's behaviour focuses on effectively cope with stress as well as seeking social support for important reasons. This includes seeking advice, help or information. On the other hand, Cooper and Baglioni (1988) in their study explained that the use of coping strategies is intended to suppress or prevent the effects of stress on individuals. They stated that the first step is to evaluate the mechanisms in identifying their own coping strategies. They focus on the cognitive coping techniques and the resulting behaviours. Individuals could use the denial or restructuring of the stimulus to view their environment as less stressful than it actually is. The results of their study explain that all measured coping strategies, except denial, have an impact on the measurement results. The use of exercise, humour, talking about the issue, and trying to deal with it seem to reduce mental health problems. On the other hand, the use of drugs and the internalization of feelings contribute to unhealthy mental and physical.

Coping strategies are important towards psychological well-being and are able to counteract the stress and burnout in the counselling service (Jordaan et al., 2007; Onoyase, 2015; Jones et al., 2016). On the other hand, Wilkerson (2009) pointed out that stress-strain coping theory (Lazarus \& Folkman, 1984) showed that, without adequate coping skills, high levels of stress could lead to increased symptoms of burnout. In addition, Lee et al. (2018) also argued that to prevent burnout, counsellors should proactively develop elements of self-monitoring and coping skills as well as implement self-care strategies. Coping strategies are very helpful to counsellors as well as guidance and counsellor teachers in order to best serve their clients. 


\section{The Importance of Coping Strategies for the Psychological Well-Being}

Jordaan et al. (2007) found that counsellors who were actively using the coping strategy, reported a very low burnout level. His findings suggested that the counsellor's coping strategy for work stress could prevent the symptoms of burnout. He emphasized the importance of understanding coping strategies that could reduce counsellors' burnout, especially when they face work demands. In addition, he proposed that coping strategy program to be recommended for South African psychological counsellors in their practice and training while fostering their emotional health through psychotherapy and support groups. In addition, Jones et al. (2016) found that coping strategies could help reduce the risk of traumatic stress and maintain the health of professionals including counsellors. Meanwhile, Jones et al. (2016) explored the relationship between coping strategies and psychological effects as a result of traumatic exposure as well as looking at the differences between five different groups of health professionals, social workers, nurses, counsellors, psychologists and medical personnel. Psychologists and counsellors reported the highest use of a coping strategy, while doctors and nurses reported the lowest use of coping strategies. In short, healthcare professionals are exposed to a variety of challenges and adopt a moderate level of coping strategy. Therefore, personal and professional self-care become necessary in addition to social support from friends, family and peers.

Furthermore, Wallace, Lee and Lee (2010) found the disengagement and self-distraction coping strategy and humour to positively mediate the relationship between ambiguity of the role and burnout. Whereas, active coping strategies negatively moderated the relationship between workload and burnout. According to him, it is important to understand the coping that could reduce the fatigue among counsellors, specifically when they are faced with specific job stress demands. The role of supervision is important in which the counsellor should be constantly monitoring and nurturing. Supervision is able to guide the counsellors especially the abused counsellors to understand their internal mechanisms. This, in turn, helps them to identify their current coping strategies as well as explore effective alternative coping strategies, especially for novice abused counsellors (Wallace et al., 2010). Looking at it from a broad perspective, Wilkerson (2009) concluded that the ability of school counselors to provide comprehensive services is associated with increased levels of stress and burnout. Levels of organizational stress and individual approaches to acting also have strong predictive value on burnout. According to him, in a personal development, counselors need to first change the coping strategy.

From the other point of view, Fye, Gnilka, \& Mc Laulin (2018) proposed to focus on reducing the use of emotion-avoidance coping processes, while strengthening the use of problem-solving and emotionally active coping processes that might help reduce stress and burnout level as a whole. Meanwhile, Pow \& Cashwell (2017) found that mental health counsellors dealing with post-traumatic stress 
disorder could be helped by establishing emotionally focused behaviors consisting of adult attachment security, emotion regulation and awareness. Some simple skills for improving emotionally focused behaviors need to be exposed to counsellors dealing with issues of disaster trauma.

Therefore, coping strategies are an important element for counsellors in general and guidance and counselling teachers in particular to be in a good state of mind and to maintain good mental health which would also affect work performance in counselling services. Studies by (Jordaan et al. 2007; Onoyase, 2015; Jones et al., 2016) found that coping strategies could overcome stress among psychologists and counsellors while also be beneficial to the stress experienced by ordinary teachers (Mapfumo \& Chitsiko, 2012; Bibi et al., 2015; Eren, 2016, Carnicer et al., 2018; Carnicer \& Calderon, 2012). In addition, emotional intelligence also contributes to positive coping strategies (Bibi et al., 2015) and it has been identified that emotional intelligence could have better contribution than coping strategies (Eren, 2016). In brief, coping strategies could help counsellors as well as guidance and counselling teacher to manage their emotions and stress level while facing various types of challenges every single day.

\section{Conclusion}

The findings of the study on counsellors' coping strategies and psychological well-being give practical information on professional training in order to maximize counsellors' psychological well-being. Coping strategies and psychological well-being are an important subject to be included as an elective course in the syllabus of guidance and counselling programs at universities as well as at educational institutes. Taking early and proactive action makes it possible to train and produce counsellors who would become better guidance and counselling teachers in schools. The process of training and the application of knowledge and appropriate strategies enable teachers and counsellors to be prepared to face the challenges of the working life. Meanwhile, the Ministry of Education Malaysia (MOE) could use the model of psychological well-being as a guide before devising a new policy related to teaching services, especially the counselling services profession, which is facing a growing number of student issues. The MOE's initiative in improving teachers should take particular note of the psychological well-being in order to encourage future teachers to be strong and capable of maintaining good self-care.

In addition, this era of globalization needs strong guidance and counselling teachers who could adapt to the changing demands in the 21 st century education. Furthermore, high quality school counsellors in both the personal and professional aspects can impact student's self-identity and national development (Salleh et al., 2013). There are still few studies that explore the coping strategies and psychological well-being for guidance and counselling teachers in secondary school. Western researchers are also proposing to examine the contribution of coping towards the well-being of counsellors (Mullen \& Crowe, 2017; Mullen \& 
Gutierrez, 2016; Fye et al., 2018). Therefore, this paper suggests a well-designed study to look at the level of coping strategies and psychological well-being of guidance and counselling teachers while exploring these two factors in-depth through qualitative research. Hopefully, these early efforts would facilitate the MOE to develop appropriate strategies to produce strong guidance and counselling teachers who are prepared to embrace innovation and changes.

\section{Acknowledgements}

These researchers would like to acknowledge the Faculty of Education for the financial funding of this research through Research Grant GG-2019-027 and PP-FPEND-2019.

\section{Conflicts of Interest}

The authors declare no conflicts of interest regarding the publication of this paper.

\section{References}

Abu Yazid, A. B. (2016). Counseling and Guidance for Malaysian Gifted Students: A Conceptual Framework. Journal for the Education of Gifted Young Scientists, 4, 21-29. https://doi.org/10.17478/JEGYS.2016115332

Azlin Norhaini, M., Jayanthi, S., Mohamed Yusoff, M. N., Nurfaradilla, M. N., \& Jamalullail, A. W. (2017). Teacher Perceptions of Managing Indiscipline amongst at-Risk Teenage Students: A Malaysian Study. International Journal of Advanced and Applied Sciences, 4, 112-119. https://doi.org/10.21833/ijaas.2017.05.020

Bardhoshi, G., Schweinle, A., \& Duncan, K. (2014). Understanding the Impact of School Factors on School Counselor Burnout: A Mixed-Methods Study. The Professional Counselor, 4, 413-416. https://doi.org/10.15241/gb.4.5.426

Beaumont, E., Durkin, M., Hollins Martin, C. J., \& Carson, J. (2016). Measuring Relationships between Self-Compassion, Compassion Fatigue, Burnout and Well-Being in Student Counselors and Student Cognitive Behavioral Psychotherapists: A Quantitative Survey. Counseling and Psychotherapy Research, 16, 15-23.

https://doi.org/10.1002/capr.12054

Bibi, F., Kazmi, S. F., Chaudhry, A. G., \& Khan, S. E. (2015). Relationship Between Emotional Intelligence and Coping Strategies among University Teachers of Khyber Pakhtunkhwa. Pakistan Journal of Science, 67, 81-84.

Biggs, A., Brough, P., \& Drummod, S. (2017). The Handbook of Stress and Health: A Guide to Research and Practice, HLM. New York: John Wiley \& Sons, Ltd. https://doi.org/10.1016/S0074-6142(13)62965-4

Bilot, J. (2012). The Relationship between Wellness and Burnout among Novice Counselors Institution: Florida Atlantic University.

Can, N. (2018). Caring for Beginning Counselors: The Relationship between Empathy, Supervisory Working Alliance, Resilience, Wellness, and Compassion Fatigue among Counselors-in-Training. Corpus Christi, TX: Texas A\&M University-Corpus Christi.

Carnicer, J. G., \& Calderon, C. (2012). Coping Strategies and Psychological Well-Being among Teacher Education Students Coping and Well-Being in Students. European Journal of Psychology of Education, 28, 1127-1140. 
Carnicer, J. G., Calderon, C. Flores, A. B., \& Bara, F. E. (2018). Role of Coping Responses in the Relationship between Perceived Stress and Psychological Well-Being in a Sample of Spanish Educational Teacher Students. Psychological Reports, 122, 380-397.

Carver, C. S., Scheier, M. F., \& Weintraub, J. K. (1989). Assessing Coping Strategies: A Theoretically Based Approach. Journal of Personality and Social Psychology, 56, 267-283. https://doi.org/10.1037/0022-3514.56.2.267

Clarke, A. T. (2006). Coping with Interpersonal Stress and Psychosocial Health among Children and Adolescents: A Meta-Analysis. Journal of Youth and Adolescence, 35, 11-24. https://doi.org/10.1007/s10964-005-9001-x

Coaston, S. C. (2017). Self-Care through Self-Compassion: A Balm for Burnout. The Professional Counselor, 7, 285-297. https://doi.org/10.15241/scc.7.3.285

Cooper, C. L., \& Baglioni, A. J. (1988). A Structural Model Approach toward the Development of a Theory of the Link between Stress and Mental Health. British Journal of Medical Pathology, 61, 87-102. https://doi.org/10.1111/j.2044-8341.1988.tb02767.x

Copley, L. A. (2013). Checking Yourself Burnout and Compassion Fatigue. The Counselor Education Newsletter, 7, 1-3.

Cummins, P. N., Massey, L., \& Jones, A. (2007). Keeping Ourselves Well: Strategies for Promoting and Maintaining Counselor Wellness. Journal of Humanistic Counseling, Education and Development, 46, 35-50. https://doi.org/10.1002/j.2161-1939.2007.tb00024.x

De Ridder, D. (1997). What Is Wrong with Coping Assessment? A Review of Conceptual and Methodological Issues. Psychology and Health, 12, 417-431.

https://doi.org/10.1080/08870449708406717

Eren, A. (2016). Unidirectional Cycles of Boredom, Boredom Coping Strategies, and Engagement among Prospective Teachers. Social Psychology of Education, 19, 895-924. https://doi.org/10.1007/s11218-016-9348-8

Farisma, R. (2017). Hubungan Antara Kesejahteraan Diri Dan Kecerdasan Emosi Dalam Kalangan Kaunselor Di Selangor, Malaysia. Malaysia: Tesis Sarjana, Fakulti Pengajian Pendidikan, Universiti Putra Malaysia.

Figley, C. R. (2002). Compassion Fatigue: Psychotherapists' Chronic Lack of Self Care. Journal of Clinical Psychology, 58, 1433-1441. https://doi.org/10.1002/jclp.10090

Friedman, K. (2017). Counselor Self-Care and Mindfulness. Contemporary Buddhism, 18, 321-330. https://doi.org/10.1080/14639947.2017.1373437

Fye, H. J., Gnilka, P. B., \& Mc Laulin, S. E. (2018). Perfectionism and School Counselors: Differences in Stress, Coping, and Burnout. Journal of Counseling \& Development, 96, 349-360. https://doi.org/10.1002/jcad.12218

Goodman, F. R., David J. D., Todd B. K., \& Scott B. K. (2017). Measuring Well-Being: A Comparison of Subjective Well-Being and PERMA. The Journal of Positive Psychology, 13, 321-332. https://doi.org/10.1080/17439760.2017.1388434

Heintzelman, S. J. (2018). Eudaimonia in the Contemporary Science of Subjective Well-Being: Psychological Well-Being, Self-Determination, and Meaning in Life. In E. Diener, S. Oishi, \& L. Tay (Eds.), Handbook of Well-Being. Salt Lake City, UT: DEF Publishers. https://doi.org/10.4324/9781351231879-14

Huat, C. S. (2018). The Relationship between Role Conflict and Burnout among Secondary School Counselors in Sarawak. Global Business and Management Research: An International Journal, 10, 10-22.

Hunter, S. T. (2016). Beyond the Breaking Point: Examining the Pieces of Counselor Burnout, Compassion Fatigue and Secondhand Depression. VISTAS. 
https://www.counseling.org/docs/default-source/vistas/article 91 2016.pdf

Jafny, J. (2012). Pengaruh Faktor Personaliti Tekanan Kerja Dan Kecerdasan Emosi Terhadap Kepuasan Kerja Kaunselor Sekolah Menengah Negeri Selangor. Malaysia: Tesis Sarjana, Fakulti Pengajian Pendidikan, Universiti Putra Malaysia.

Jones, S. M., Terte, I., \& Stephens, C. (2016). Secondary Traumatic Stress, Vicarious Posttraumatic Growth, and Coping among Health Professionals; A Comparison Study. New Zealand Journal of Psychology, 45, 20-29.

Jordaan, I., Spangenberg, J. J., Watson, M. B., \& Fouche, P. (2007). Emotional Stress and Coping Strategies in South African Clinical and Counseling Psychologists: Being a Psychologist Can Be Satisfying and Rewarding but also Demanding and Stressful. South African Journal of Psychology, 37, 835-855. https://doi.org/10.1177/008124630703700411

Keyes, C. L. M. (1998). Social Well-Being. Social Psychology Quarterly, 61, 121-140. https://doi.org/10.2307/2787065

Kim, N., \& Lambie, G. W. (2018). Burnout and Implications for Professional School Counselors. The Professional Counselor, 8, 277-294.

https://doi.org/10.15241/nk.8.3.277

Krok, D. (2008). The Role of Spirituality in Coping: Examining the Relationships between Spiritual Dimensions and Coping Styles. Mental Health, Religion and Culture, 11, 643-653. https://doi.org/10.1080/13674670801930429

Lazarus, R., \& Folkman, S. (1984). Stress, Appraisal and Coping. New York: Springer Publishing Company, Inc.

Lee, I., Bardhoshi, G., Yoon, E., Sandersfeld, T., Rush, R. D., \& Priest, J. B. (2018). Attributional Style and Burnout of Counselors-in-Training. Counselor Education \& Supervision, 57, 285-300. https://doi.org/10.1002/ceas.12117

Lu, L. (1989). Individual Differences in Vulnerability to Stress. Oxford: Oxford University.

Mapfumo, J. S., \& Chitsiko, N. (2012). Teaching Practice Generated Stressors and Coping Mechanisms among Student Teachers in Zimbabwe. South African Journal of Education, 32, 155-166. https://doi.org/10.15700/saje.v32n2a601

Mc Leod, J., \& Mc Leod, J. (2014). Personal and Professional Development for Counselors, Psychotherapists and Mental Health Practitioners. New York: McGraw Hill Education.

Mullen, P. R., \& Crowe, A. (2017). Self-Stigma of Mental Illness and Help Seeking Among School Counselors. Journal of Counseling and Development, 95, 401-411. https://doi.org/10.1002/jcad.12155

Mullen, P. R., \& Gutierrez, D. (2016). Burnout, Stress and Direct Student Services among School Counselors. The Professional Counselor, 6, 344-359. https://doi.org/10.15241/pm.6.4.344

Mullen, P. R., Blount, A. J., Lambie, G. W., \& Chae, N. (2017). School Counselors' Perceived Stress, Burnout, and Job Satisfaction. Professional School Counseling, 21. https://doi.org/10.1177/2156759X18782468

Ng, H. K. (2015). Pengaruh Kesejahteraan Kaunselor Terhadap Penglibatan Kerja Dalam Kalangan Kaunselor Di Malaysia. Malaysia: Tesis Sarjana, Fakulti Pengajian Pendidikan, Universiti Putra Malaysia.

Nor Hayati, M. N. (2014). Family Counseling in Malaysia: Current Issues and Practices. International Education Studies, 7, 33-39. https://doi.org/10.5539/ies.v7n13p33

Noriah, M. I., \& Abu Yazid, A. B. (2014). Counseling Services for Malaysian Gifted Stu- 
dents: An Initial Study. International Journal Advanced Counseling, 36, 372-383.

Onoyase, A. (2015). Stress Coping Strategies among Guidance Counselors in the Performance of Their Jobs in Secondary Schools Delta North Senatorial District. Journal of Education and Practice, 6, 111-116.

Pow, A. M., \& dan Cashwell, C. S. (2017). Posttraumatic Stress Disorder and Emotion-Focused Coping among Disaster Mental Health Counselors. Journal of Counseling \& Development, 95, 322-331. https://doi.org/10.1002/jcad.12146

Prema, M. (2011). Konflik Peranan Dan Tekanan Dalam Kalangan Guru Bimbingan Dan Kaunseling Sepenuh Masa Sekolah-Sekolah Menengah Di Zon Semenyih. Malaysia: Kertas Projek Sarjana, Fakulti Pengajian Pendidikan, Universiti Putra Malaysia.

Puig, A., Baggs, A., Mixon, K., Park, Y. M., Kim, B. Y., \& Lee, S. M. (2012). Relationship between Job Burnout and Personal Well Ness in Mental Health Professionals. Journal of Employment Counseling, 49, 98-109. https://doi.org/10.1002/j.2161-1920.2012.00010.x

Release Letter of Ministry of Education (MOE) (2012) Number 12.

Ryff, C. D. (1989). Happiness Is Everything, Or Is It? Explorations on the Meaning of Psychological Well-Being. Journal of Personality and Social Psychology, 57, 1069-1081. https://doi.org/10.1037/0022-3514.57.6.1069

Ryff, C. D. (1995). Psychological Well-Being in Adult Life. Current Directions in Psychological Science, 4, 99-104. https://doi.org/10.1111/1467-8721.ep10772395

Ryff, C. D., \& Keyes, C. L. M. (1995). The Structure of Psychological Well-Being Revisited. Journal of Personality \& Social Psychology, 69, 719-727. https://doi.org/10.1037/0022-3514.69.4.719

Salleh, A., Kamarul, M. S., Zuria, M., Amla, M. S., Rosseni, D., \& Mohd Izwan, M. (2013). Initial Development and Validation of Multicultural Counseling Competencies Scale for Malaysian School Counselors. Asian Social Science, 9, 144-152.

https://doi.org/10.5539/ass.v9n17p144

Simpson, S., Simionato, G., Smout, M., Vreeswijk, M. V., Hayes, C., Sougleris, C., \& Reid, C. (2018). Burnout amongst Clinical and Counseling Psychologists: The Role of Early Maladaptive Schemas and Coping Modes as Vulnerability Factors. Clinical Psychology \& Psychotherapy, 26, 35-46. https://doi.org/10.1002/cpp.2328

Skovholt, T. M., Grier, T. L., \& Hanson, M. R. (2001). Career Counseling for Longevity: Self-Care and Burnout Prevention Strategies for Counselor Resilience. Journal of Career Development, 27, 167-176. https://doi.org/10.1177/089484530102700303

Smith, K. L. (2017). Self-Care Practices and the Professional Self. Journal of Social Work in Disability \& Rehabilitation, 16, 186-203. https://doi.org/10.1080/1536710X.2017.1372236

Wallace, S. L., Lee, J., \& Lee, S. M. (2010). Job Stress, Coping Strategies and Burnout among Abuse-Specific Counselor. Journal of Employment Counseling, 47, 111-122. https://doi.org/10.1002/j.2161-1920.2010.tb00096.x

Wilkerson, K. (2009). An Examination of Burnout among School Counselors Guided by Stress-Strain-Coping Theory. Journal of Counseling \& Development, 87, 428-437. https://doi.org/10.1002/j.1556-6678.2009.tb00127.x

Young, M. E., \& Lambie, G. W. (2007). Mental Health Systems: Organizational Influences. Journal of Humanistic Counseling, Education and Development, 46, 98-114. https://doi.org/10.1002/j.2161-1939.2007.tb00028.x 